\title{
DECOUPLING IN THE PERSPECTIVE OF RESPONSIBILITY
}

\author{
Anna Adamus-Matuszyńska ${ }^{1}$, Grzegorz Polok ${ }^{2}$ \\ Department of Public Management and Social Sciences, University of Economics in Katowice, \\ ul. 1 Maja 50, Katowice, Poland \\ E-mails: 'anna.adamus-matuszynska@ue.katowie.pl(corresponding author); \\ ${ }^{2}$ grzegorz.polok@ue.katowice.pl
}

Received 05 March 2020; accepted 07 May 2020

\begin{abstract}
The principal objective of the article is to examine responsibility as a value helping to enhance the ability of organisation to deal with highly institutionalised environment in which it operates, and which has an impact on the decoupling process. The authors put forward a hypothesis that the development of the sphere of responsibility may support to deal with the complexity of organisation and its environment. To verify the hypothesis the review of literature was undertaken as the research method. Decoupling process is neither good nor bad although it bears ethical dilemmas. The results of the literature examination let to make the conclusion that responsibility is a value that allows organization to solve dilemmas resulting from the complexity and controversy of the decoupling phenomenon. The authors propose to concentrate on the individuals managing and co-forming the organisation in the light of responsibility.
\end{abstract}

Keywords: decoupling, responsibility, ethics, management, communication.

JEL Classification: D23, M14.

\section{Introduction}

The organisation, its structures, culture and processes occurring in it are shaped by specific people. What is more, individuals co-create the collective of the organisation (Brown, 1997; Hatch \& Schultz, 2002; Schein, 2004), bringing in their identities, potentials, ideas, aspirations and pursued goals (Argiris, 1990). In consequence, the operation of a given organisation is the resultant of actions taken by individuals (Driskell \& Salas, 1992).

When individuals make organised effort to perform an undertaking, a necessity arises to create mutual ties and a proper communication system (Foltz \& Martin, 2008). In addition, a need arises to manage a given team well and to be able to subject oneself to the required guidelines, procedures and structure. In the perfect organisational mode, both the manager and employees should make effort to understand one another and properly determine the way they take action and the methods for achieving a set goal. Lack of such understanding, and cooperation, may lead to more difficulties in performing a task or even prevent the goal to be achieved. Therefore, it is often the case that the management has to face the problem of applying the proper method and using the appropriate tools, aiming to motivate and lead the contractors truthfully to obtain the desired effect. Unfortunately, it happens that despite the efforts and procedures, the final effect does not meet the expectations of the environment, both internal and external. A lot of organisation researchers since the time of Max Weber have been focusing on building rational organisation models (Scott, 1987), assuming that the logic in activity will ensure effectiveness and efficiency. As a result, they assume that to make actions taken in a given organisations effective, proper procedures of conduct must be formulated and implemented, which will ensure that the expected effects will be obtained. In the classical text on decoupling Meyer and Rowan assumed that the rationalised institutions create myths of formal structure which shape organisations (Meyer \& Rowan, 1977 , p. 350). What is more, an organisation is under a strong influence of the internal and external environments, the expectations of which they want to, and sometimes have to, fulfil. Consequently, if an organization wants to survive, it must act in accordance with these myths and ensure its efficiency. The environment expects certain ceremonies on the one hand, and productivity on the other, which gives rise to certain inconsistencies. Organisations are not only under some social environment pressure (Meyer \& Rowan, 1977), they also implement modern technologies, solutions or scientific ideas, which do not have to be connected with their basic activity (Bromley \& Powell, 2012, p. 5) but are required by stakeholders (e.g. intro- 
duction of ISO standards). In such a situation, proper activities are taken to present given procedural and structural solutions and methods for their implementation. It turns out that the effectiveness of such behaviour is sometimes poor. Despite strong efforts, expected results are nowhere to be seen. Such a situation is, therefore, referred to as decoupling, i.e. the emergence of a gap between the implemented principles of conduct and concrete practice. Even though the process itself is as old as the efforts to organise social life, a take at defining and diagnosing it is quite new. Since the publication of the classic definition of decoupling by Meyer and Rowan (1977), the literature and studies have been developing systematically (Westphal \& Zajac, 2001; Bromley \& Powell, 2012). Decoupling is one of the results of isomorphism with an elaborated institutional environment (others are: rituals on confidence and the avoidance of inspection and evaluation), which is characterised by professionalisation, technical performance, ceremonies and focus mainly on human relations (Boxenbaum \& Jonsson, 2017). The decoupling process allows to maintain formal structures and at the same time not to meet the expectations and needs of the environment (Meyer \& Rowan, 1977, p. 357).

This paper reflects over the process of decoupling and attempts to indicate potential directions of studies that might to narrow the said gap between organisational procedures and environment expectations, which is an abnormality, even if it does lead to any consequences negative for the organisation. Although the classic authors describing the concept do not define decoupling as something negative, merely describing it and indicating its causes, from the point of view of the rational theory of organisation the process of formation of a gap between the policy and the practice (Bromley \& Powell, 2012) is not only irrational, but also ethically dubious (MacLean \& Behnam, 2017), which forms the thesis of this paper. The problem results from the dilemma faced by both managers and employees, a moral dilemma: whether to implement the principles expected by the external surroundings and agree to the activity of the organisation that does not comply with them or formulate such principles of organisation's activity which go along with its nature, but do not meet the needs of the surroundings halfway. An example of such dilemma is the activity referred to as CSR - corporate social responsibility - which is sometimes seen as non-cohesive with the actual activity of the organisation (Christensen et al., 2013). Decoupling is - in the most general way - the separation of social environment expectations from their implementation by the organization, the possibilities of the organization from its readiness to take advantage of them, the people from structures that they create. This phenomenon may take a decreasing or increasing tendency depending on changes in the environment and the organizations themselves. Therefore, mechanisms of interdependence of organizational policy and implemented practice should be sought. Decoupling is not a strategic decision taken by organizations, but an organizational solution to deal with environmental demands, which can be competing or difficult to combine with intra-organizational priorities. Bromlay and Powell distinguish two kinds of decoupling: policy - practice, which they assume declines and means - ends, which decreases. As they finally conclude, there is a need for more reflective and proactive responses to external pressures (Bromlay \& Powell, 2012, p. 37). One of the ways to deal with decoupling as the organisational challenge to react to environment is to put strong emphasis on the essence of the responsibility of individual and organisation. It turns out that proper diagnosis of the essence of responsibility combined with identification of its obligatory nature may, to a considerable extent, contribute to overcoming the problem of decoupling, which occurs between that which is expected to be implemented and that which has actually occurred.

The deliberations presented below result from the analysis of the literature on organisation, management studies, ethics and social responsibility. Thanks to a synthetic take, the phenomenon of individual responsibility will be presented, particularly in terms of morality, combined with the indication of a significant role played by that attitude in building community relations in the organisation. Such an approach allows to indicate the possibility to minimise the process of decoupling as a phenomenon giving rise to myths and driving hypocrisy in the operation of the organisation (Brunsson, 1985, 1989). The theoretical implication was formulated on the basis of the analysis of proper definitions and from the application of significantbased theories of understanding. The ultimate purpose of the presented deliberations is the recommendation that may pose a potential solution to solve the problems arising due to the decoupling of activities performed in the organisation to put the emphasis of attitudes of responsible behaviour of all people forming a given organisation as well as responsibility towards the established policies, structures and principles. 


\section{Decoupling and management in the organisation}

Each organisation, if it wants to function rationally, should be directed by some managerial entities, which can be seen in the specific process of organisation of a given whole. It is made by uniting individual people linked with a given organisation around the problems and tasks put before them to be resolved and performed. The whole, therefore, seems to be a complicated system of interdependencies using specified procedures to achieve the set aspirations (Chrisidu-Budnik et al., 2005). Moreover, the process of management requires proper coordination of each part of the organisation to be economical, effective and ethical (Gasparski, 2007, p. 542) or - according to Elkington (1994) - to take into account the $3 \mathrm{P}$ People, Planet and Profit.

In the second half of the 20th century, attention started to be paid in the field of managerial activities to specific situations related to decoupling. For better management and administration of the activities performed by a given organisation, special activities are taken that aim to boost the efficiency, improve the mobilisation of individuals, raise quality and effectiveness of performed work and adapt the activities of the organisation to the currently effective requirements regarding the natural and social environment. It is achieved through various strategies and procedures or simply by specific operating assumptions. However, many a time a closer analysis of these actions showed that the expected effects or changes did not occur. It resulted not from subject-matter mistakes, but rather from resistance of the social environment. The principles were implemented only at a formal level. They were not acknowledged in the collective they pertained to; in effect, they were never applied properly. They became an impracticable, symbolic institution. Despite the conviction among the leaders of the need to carry out changes or reforms, they did not find recognition in the environment they were supposed to concern. The consequence has become a kind of separation between what is intended and what is implemented. Therefore, a dissonance between a given theory and the practices is taken later on. However, this is not the only form of decoupling. J. W. Meyer and B. Rowan paid attention to this, indicating that "... structural elements are only loosely linked to each other and to activities, rules are often violated, decision are often unimplemented and have certain consequences, technologies are problematic efficiency, and evaluation and inspection systems are subverted or rendered so vague as to provide little coordination" (Meyer \& Rowan, 1977, p. 343).

The causes of such decoupling are diverse. The first group of causes involves the environmental pressure (Meyer \& Rowan, 1977; Tolbert \& Zucker, 1983; Westphal et al., 1997; Henisz \& Zelner, 2005) and the phenomenon of isomorphism (DiMaggio \& Powell, 1983). The other group of causes is connected with intra-organisational processes such as too strong complication or complexity of imposed tasks or intentionally making the activities of the organisation confidential (Scott, 2008). In turn, Bromley and Powell (2012, p. 517) suggest the following causes: a) there is too strong emphasis on the implementation of principles themselves, b) principles are applied selectively, c) there is environmental pressure, it can lead to change in behaviour and the results being worked on regardless of the implemented principles. So, decoupling is preconditioned by two pressures: external and internal, which result from changes occurring in the general surroundings of the organisation.

Therefore, attempting to specify decoupling (it is difficult to pinpoint one proper definition of this multifaceted and multidimensional phenomenon), it might be described as some kind of discrepancy between the principles established by a given organisation knowingly and intentionally and the practice pursued in that organisation, which implements procedures and principles different than the assumed ones in order to achieve the basic goals of that organisation. However, this process is validated in the organisation in various ways; therefore, it ensures that it operates lawfully. Nevertheless, these activities are evaluated by various beholders - both internal and external - who monitor given organisations in terms of the actual compliance with and implementation of the established principles if there is a lack of trust or good faith (Haack \& Schoeneborn, 2015, p. 307).

The phenomenon under examination may be of various nature, resulting for instance from numerous ways in which it occurs and is classified. It is presented in Table 1.

Considering the characteristics of both types of decoupling, it can be seen that this phenomenon is at all controversial. One of the first reasons of the decoupling are activities where various principles are presented, planned to be established in a given organisation but eventually not implemented. In a way, these principles exist symbolically and are not reflected in taken action. 
Table 1. Overview of decoupling types (source: Bromley \& Powell, 2012, p. 8)

\begin{tabular}{|c|c|c|c|}
\hline Type & Description & Key insight & Key consequences \\
\hline \multirow[t]{2}{*}{$\begin{array}{l}\text { Policy- } \\
\text { practice }\end{array}$} & $\begin{array}{l}\text { Formal rules systematically } \\
\text { violated and unimplemented }\end{array}$ & $\begin{array}{l}\text { Explains why organiza- } \\
\text { tions routinely adopt poli- } \\
\text { cies and do not implement } \\
\text { them }\end{array}$ & $\begin{array}{l}\text { Legitimacy or resources or both; adop- } \\
\text { tion may be ceremonial }\end{array}$ \\
\hline & $\begin{array}{l}\text { Evaluation/ inspection is } \\
\text { not present or is intended as } \\
\text { a symbolic act. It is so } \\
\text { vague that it provides little } \\
\text { relevant information }\end{array}$ & & $\begin{array}{l}\text { Buffering of core activities; may pro- } \\
\text { mote efficiency or protect interests of } \\
\text { internal constituents }\end{array}$ \\
\hline \multirow[t]{4}{*}{$\begin{array}{l}\text { Means- } \\
\text { ends }\end{array}$} & $\begin{array}{l}\text { Rules and policies imple- } \\
\text { mented, but with uncertain } \\
\text { relationship to } \\
\text { outcomes }\end{array}$ & $\begin{array}{l}\text { Explains why organiza- } \\
\text { tions dedicate resources to } \\
\text { practices that have little } \\
\text { known relationship to } \\
\text { intended goals }\end{array}$ & Legitimacy \\
\hline & $\begin{array}{l}\text { May be multiple } \\
\text { unrelated goals }\end{array}$ & & $\begin{array}{l}\text { Implementation contributes to organiza- } \\
\text { tional heterogeneity and complexity }\end{array}$ \\
\hline & & & $\begin{array}{l}\text { If evaluation and inspection are present, } \\
\text { generates continual periods of reform } \\
\text { when inconsistencies are revealed }\end{array}$ \\
\hline & & & $\begin{array}{l}\text { Rational allocation of resources from } \\
\text { purely instrumental perspective; can } \\
\text { direct time and attention away from } \\
\text { core goals }\end{array}$ \\
\hline
\end{tabular}

As a result, some kind of ceremonialism appears in their recognition, but the expected results do not appear as they are not reflected in practice in any actual manner whatsoever. An example of such actions can be the strategy of social responsibility, formulated and communicated in a ceremonial manner, though forgotten in every-day life of the organisation (Doane, 2004). A situation may also occur when there are principles in an organisation, and they are even being implemented, but there is no system controlling their application in place or such a system is so unclear and multifaceted that it not transparent at all. As result, it is not possible to introduce any unambiguous, rational and correct solutions. The consequences may made confusion in the organisation. In turn, the effectiveness of principles is of ad hoc, subjective and utilitarian nature. An example might be the behaviours being part of the cultural ceremonialism in a given organisation, which aim not to improve the operating conditions but to make the taken decisions ultimate or generate better financial profit (Bijlsma-Frankema \& Koopman, 2004; Hewege, 2012).

However, other situations may occur as well. At times, there are aspirations to formulate, implement and promote various principles, but from the point of view of the organisation, they are of little merit and it might even happen that their formulation is groundless. In effect, there are some effects of their implementation, change or transformation, but it cannot be actually determined whether these effects result from those principles. The consequences usually bear different results then. It often turns out that the potentially implemented principles are to make final and ultimate such activities that do not necessarily result from such principles (e.g. bureaucracy in document circulation). In effect, it may lead to a situation where an organisation is seen as non-homogeneous and having complex structure where the organisation's cohesion, transparency and homogeneity is lost (Johnson et al., 2010).

The process of decoupling may also occur during the update of strategies and principles in the organisation. As a result, errors or weaknesses are identified and indicated that had an impact on work effectiveness. An example might be the irrationality of the practice of a given organisation resulting from the effect of heuristics on the decisionmaking process (Kahneman \& Tversky, 1971, 1973, 1974). An irrational allocation of tasks or resources, resulting from decision made on the basis of heuristics and not rational process of available information processing, leads to undertaking such ventures where the effort of the organisation 
and its employees was put in little significant tasks at the cost of the achievement of the fundamental and reasonable goals (Brunsson, 1982).

The presented situations affect all activity of the management as well as the employees. It turns out that on the one hand there is a need to implement some changes, aiming first of all to boost the effectiveness of performed work, but on the other the implemented procedures do not reflect the set goals. They are idealised, too difficult to implement, implemented incorrectly, incomprehensible for the recipients and sometimes even redundant. The creativity of ideas and willingness to improve the former principles of operation may, therefore, prove ineffective and in extreme situations may even lead to organisational chaos. What is more, the gap forming between the declared strategies, procedures and standards and the organisational practice on the one hand leads to moral dilemmas of the management and the employees and - on the other - it may result in making activities unethical only to meet the expectations imposed on the organisation. Therefore, decoupling requires in-depth analysis not only in terms of the theory of organisation, but also in terms of the theory of business ethics.

\section{Free and responsible activities}

It is not easy to counteract decoupling. Establishing new principles and enacting new legal documents will not solve the problem. If the efforts to implement new principles have not worked so far, establishing new standards will not help at all. It seems that, apart from procedural solutions, focus on ethical activities might be effective.

It must be stressed that when seeking solutions to the ambivalence of decoupling in the science of ethics, it is defined as a normative science, which "establishes the moral foundations and principles of human activity" (Ślipko 1974, p. 17), so there is reference to human morality. Morality is the foundation of life of an individual because one cannot get rid of morality or go beyond it $(\mathrm{Bu}-$ chanan, 2009). Each human factor appears in the sphere of some moral good or evil and the sphere of human morality assumes several constituents. Human acts are accompanied by some level of awareness and volition, so only such acts are evaluated in terms of ethics that are rational (the individual knows what they are doing) and voluntary (the individual desires what they are doing). This thesis complies with the rational theory of organisation, which allows to analyse the process of decoupling not only in terms of management, but also in terms of theories of ethics. The rationality of action is related to teleologicality, that is the finality of action, which shows in the intention of the decision being made. This, in turn, chooses moral good or evil in the act of discrimination. This choice results from freedom, to which every human being is entitled and in which a specific injunction occurs known as duty. It suggests the direction of behaviour, i.e. what should be done or what must not be done (Ślipko, 1974, pp. 203214). Therefore, duty is the essence of human activity. It normalises the life of the individual as well as introduces order in interpersonal relations, shaping social order. However, there is some danger to it: the individual may remain deaf and nonreflective to this duty. How often do we know "what we should do" and do to the contrary anyway! It turns out that as long as "you should" does not transform into "I should", there will be no breakthrough, no change in the actions of a given human being (Styczeń, 1993, pp. 100-103). In other words, the sense of morality lies in the understanding what and why should I do. If a given individual does not rationally reflect on the necessity to do the good and avoid the evil (the so-called principle of synderesis) (Hoffmann, 2011), and so does not decide to recognise the truth about the good and is not willing to choose it, the individual will remain trapped in their own combinations, getting lost on roads of personal subjectivism. In such a situation it is impossible to find understanding with other entities as the individual seals up in their own vision of reality. In other words, the "duty" will remain in the sphere of vague reality lying outside the area of interest of the individual. The individual has not understood what "they should do" and how to adapt that "duty" as their own.

What is important here, what needs to be underscored is that when the individual has made effort to realise "what they should do", they do it because they have seen some reasonable arguments, they have understood the essence of their acts. They have not done it on coercion. To the contrary, it has been their independent act of will. That which is accepted freely and knowingly must result in the voluntariness of action (Styczeń, 1993, pp. 104-106), and so responsibility.

The idea of responsibility is fundamentally connected with the fact of human free will. The understanding of this will can be twofold. On the one hand, free will seems to be a human ability to make independent decisions, not determined by the surroundings or the laws of nature, or - all the more - by any individuals with superior authority. As a result, what emerges is "the freedom built in 
the reality of moral order and subjected to the laws governing that order, the keystone and crowning of which laws is the ethical imperative of actualisation of the moral ideal that is the life of worthy human as a person" (Ślipko, 2010, p. 149). Expressed another way, inside themselves the human being finds some moral space where they can make their own decisions, being aware of them rationally and desiring them fully at the same time. This is where the other aspect of freedom appears, arising from the first one. The human being finds in themselves a natural freedom to actualise the adopted morality. It consists in adopting some values and moral principles which they accept and are willing to actualise. This leads to moral freedom, bearing specific consequences of using or neglecting it as a result of actualisation of the moral good or the moral evil. This is where the human responsibility emerges from. It includes the 'when' and the 'for what' of the human responsibility and the responsibility for proper shaping of their own moral sphere.

In conclusion, to fully assign responsibility to a given individual it is absolutely necessary to pay attention to the values directly related with such responsibility. Firstly, an act performed by the human being must be rational. The human being must know that they are doing something and understand what they are doing. Secondly, the awareness of taken initiatives should be empowered in volition as well, which means that the individual will choose decision congruent with their will if they have to make a choice. Finally, it must be assumed that the human being is fully responsible only when they understand what they are doing and when they know that they want it. In all other cases, their responsibility may be seriously limited or even fully lifted (Ślipko, 1974, pp. 56-66).

\section{Reparatory role of responsibility}

Trying to overcome the ambiguity of attitudes occurring in the process of decoupling, one might use a reference to the understanding of the essence of responsibility and to its implementation in the sphere of socioeconomic activities of respective organisations. First of all, two fundamental areas where responsibility occurs must be distinguished. The first one appears in the individual dimension of each human being, the other - in the sphere of community acts (team, i.e. organisational, acts).

Rationalisation of the activity of acts of individual organisations requires departure from the implementing individualism-conditioned changes and contesting the principles resulting from irrational persistence of maintaining the principles of action in place so far. Attempt to overcome such a state of affairs can become real by making individuals, regardless of their position in the organisation, realise the role of their responsibility in the decision-making and resulting action.

First and foremost, given individuals must be made to realise the necessity to approach the performed tasks rationally and the condition of voluntariness of action must be underlined (Wallace, 1998). In this context, a basis for realising the moral nature of each such act is created, which results in the occurrence of a dutiful act intended to actualise the good and reject any form of the evil. Such an attitude is accompanied by yet another element of this complex situation. The human being realises that they are responsible for each such act - both in the ethical and legal realm. It is worth pointing out here that the fact that the legal dimension of sanctions resulting from, for instance, failure to meet the obligations imposed on the individual formerly is an expression of "secondary responsibility" (accountability). This is so as such a situation can happen, and can have a sanctioning power, only because ontological responsibility occurred first. Penal consequences are, therefore, merely secondary to the state of affairs that occurred earlier.

It is worth noting here that the permanent shaping of a human being in the ethical attitude facilitates developing their inclination to perform good acts and reject evil acts. The human being is then sensitive to the moral good and as a result is inclined to act rationally and properly. They also realise that various interpersonal arrangements impose certain duties on them for which they are responsible and from which they cannot departure or be released.

In consequence, the "sense of duty" emerges, which is not a blind habit, or a sign of some fear of sanctions, but a rational, free and responsible fulfilment of what should be fulfilled. In a wider perspective, the merit of the axiological sphere needs to be underscored as well. By conscious, free and rational determination of a situation, a given individual sees various values for which they are responsible, and which play a considerable role not only in their life, but also in their surroundings, in their relations with others, in a team and in a given organisation (Kosewski, 2008, pp. 67-86; Górniak, 2015, pp. 101-116; Dolan et al., 2008, p. IX). It is impossible to indicate all references (both positive and negative) that occur in responsible relations between organisation members. One thing is certain as it results from the normative approach to the issue: the individual, shaping their individual 
life and relating to other individuals, should always make an effort of responsibility by protection and support of these values that affirm the dignity of every human being (Gałkowski, 2003, p. 193).

If the individual consolidates the category of responsibility in themselves, they will understand how important the issue of expanding such attitudes onto other entities through the process of organisational socialisation is (Van Maanen \& Schein, 1979). This way, the category of responsibility will emerge in the social dimension of the organisation. What had a significant impact on the realisation of the role played by responsibility, e.g. in business, was the modern existentialism, indicating freedom as its foundation (Ashman \& Winstanley, 2006), which stresses the fact that there is no freedom without responsibility. In this day and age, the importance of economic freedom is highlighted as well, which indirectly emphasises the importance of responsibility as well - this is expressed in the activities initiated by a lot of organisations, especially in business. The other current having an impact on the said category of responsibility awareness was the philosophy of dialogue (Buber, 1992). In this concept, apart from the "I" the "you" of another person and relations with that another person are discovered. Indicating oneself only, a human being is responsible only towards themselves - looking at another person makes them discover the area of responsibility towards others as well (Filek, 2013, pp. 108-111).

On the basis of such tenets, what must be stressed is the role of the stakeholder theory, which has considerably contributed to the emergence of responsible strategy of enterprise management. According to this strategy, every enterprise should strive to achieve its own goals and to meet the needs of groups from their own surroundings, i.e. stakeholders, in a fair manner (Freeman, 1984; Rojek-Nowosielska \& Szczepaniak, 2003, pp. 322326). Corporate social responsibility is, therefore, understood as a responsible dialogue with all people who are really interested in the economic activity of individual organisations. Such a dialogue is held via two-way communication (two-way symmetric model) between individual entities forming a relation and, in consequence, via rational decisions and resulting outcomes (Grunig \& Hunt, 1984, pp. 22-23). The presented messages should be empowered in the axiology adequate fora given organisation and their specific nature should correspond to the policy and strategy pursued there. As a result, they can exhaustively and systematically answer to the needs of all interested stakeholders.

\section{Conclusions and discussion}

The problem of decoupling, that is a specific type of dissonance between regulations or principles (policy) and implemented practices (practice) or means (the implementation of programmes) and ends (the impacts), is a phenomenon which will occur in each and every organisation sooner or later. It is often difficult to determine what particularly causes such situations. Apart from rationalisation one of such causes is the weakness of the human nature, showing by individualism, as well as the lack of rationality in the made decisions. Attempts to prevent negative effects of decoupling and increase positive consequences of this phenomena may be different, but their effectiveness is dubious.

One of the ways to counteract not only the pejorative effects of decoupling, but also their causes might be the category of responsibility. To achieve such an attitude, organisation members must, however, be duly prepared by supporting their rationality and creating conditions for free choice. The human being who realises the role of their own responsibility will strive to actualise it and, as a result, will take consistent attempt to establish dialogue with other people, aiming to work out a consensus adequate to the problem which has cropped up. In such a way, processes of management in organisations can be rationalised and, in turn, the effectiveness of ethical action can be improved.

Societies achieve their objectives through organisations. Organisations reach their purposes through structures, processes and people. People need to act in clear frames, those which clearly exposes senses. One of them could be a responsibility framework addressed to individuals and organisation itself (Lindkvist \& Llewellyn, 2003). Following the idea of Jonas (1985), one could stress that the relations between organisation, its policies, practice and outcome are fundamental and complicated. What is needed is a new understanding of a state of mind, which one may call referring to Jonas as "imperative of responsibility". It is disputable to implement an ethical approach of responsibility in business practice. Although such a "frame" might regulate complexity of decoupling phenomena in organisations.

It was not the puropose of the presented reflection to blame the decoupling process as an unethical or immoral strategy. The main objective was to examine how to solve decoupling dilemmas which might appear when it comes to misconduct activities of organisation, its management and employees. There is a fundamental question whether the responsibility as organisational value is a theo- 
retical concept that influence on organisation to adopt new processes and structures and implement them in daily activities. If the answer is positive, then there is a need to analyse the issue how important to institutional theory is a concept of responsibility. If the answer is negative, would the notion of responsibility be insufficient for organisational studies?

\section{References}

Argiris, Ch. (1990). Integrating the Individual and the Organization. Routledge.

Ashman, I., \& Winstanley, D. (2006). Business ethics and existentialism. Business Ethics, 15(3), 218233. https://doi.org/10.1111/j.1467-8608.2006.00445.x

Bijlsma-Frankema, K., \& Koopman, P. (2004). The oxymoron of control in an era of globalisation: Vulnerabilities of a mega myth. Journal of Managerial Psychology, 19(3), 204-217. https://doi.org/10.1108/02683940410527711

Boxenbaum, E., \& Jonsson, S. (2017). Isomorphism, diffusion and decoupling: Concept evolution and theoretical challenges. In R. Greenwood, C. Oliver, T. Lawrence, \& R. E. Meyer (Eds.), The SAGE Handbook of Organizational Institutionalism ( $2^{\text {nd }}$ ed., pp. 79-104). SAGE.

Bromley, P., \& Powell, W. W. (2012). From smoke and mirrors to walking the talk: Decoupling in the contemporary world. The Academy of Management Annals, 6(1), 483-530. https://doi.org/10.5465/19416520.2012.684462

Brown, A. D. (1997). Narcissism, identity, and legitimacy. Academy of Management Review, 22(3), 643-86. https://doi.org/10.5465/amr.1997.9708210722

Brunsson, N. (1982). The irrationality of action and action rationality: Decisions, ideologies and organizational actions. Journal of Management Studies, 19(1), 29-44.

https://doi.org/10.1111/j.1467-6486.1982.tb00058.x

Brunsson, N. (1985). The irrational organization: Irrationality as a basis for organizational action and change. John Wiley and Sons.

Brunsson, N. (1989). The organization of hypocrisy: Talk, decisions and actions in organizations. John Wiley and Sons.

Buber, M. (1992). Ja i Ty. Wybór pism filozoficznych [You and I. Selection of philosophical papers]. Warsaw: Instytut Wydawniczy PAX.

Buchanan, A. (2009). Moral status and human enhancement. Philosophy \& Public Affairs, 37(4), 346-381. https://doi.org/10.1111/j.1088-4963.2009.01166.x

Chrisidu-Budnik, A., Korczak, J., Pakuła, A., \& Supernat, J. (Eds.). (2005). Nauka organizacji $i$ zarzadzania [Learning how to organise and manage]. Kolonia, Wrocław.

Christensen, L. T., Morsing, M, \& Thyssen, O. (2013). CSR as an aspirational talk. Organization, 20(3), 372-393.

https://doi.org/10.1177/1350508413478310

DiMaggio, P. J., \& Powell, W. W. (1983). The iron cage revisited: Institutional isomorphism and collective rationality in organizational fields. American Sociological Review, 48(2), 147-160.

https://doi.org/10.2307/2095101

Doane, D. (2004). Beyond corporate social responsibility: Minnows, mammoths and markets. Futures, 37(2-3), 215-229. https://doi.org/10.1016/j.futures.2004.03.028

Dolan, S. L., Richley, B. A., Garcia, S., \& Lingham, T. (2008). Zarządzanie przez wartości [Managing by values]. CEO Magazyn Top Menedżerów, September. http://ceo.cxo.pl/artykuly/59344_1/Zarzadzanie.przez.wartosci.html

Driskell, J. E., \& Salas, E. (1992). Collective behavior and team performance. Human Factors, 34(3), 277-288. https://doi.org/10.1177/001872089203400303

Elkington, J. (1994). Towards the sustainable corporation: Win-win-win business strategies for sustainable development. California Management Review, 36(2), 90-100. https://doi.org/10.2307/41165746

Filek, J. (2013). Spoteczna odpowiedzialność biznesu jako nowa wersja umowy spolecznej [Corporate social responsibility as a new version of social contract]. Księgarnia Akademicka, Kraków.

Foltz, P. W., \& Martin, M. J. (2008). Automated communication analysis of teams. In Team effectiveness in complex organizations. Cross-disciplinary perspectives and approaches. Taylor Francis.

Freeman, R. E (1984). Strategic management: A stakeholder approach. Pitman.

Gałkowski, S. (2003). Rozwój i odpowiedzialność [Development and responsibility]. Ed. KUL.

Gasparski, W. (2007). Wyktady z etyki biznesu. Nowa edycja uzupetniona [Lectures of business ethics. New version, supplemented]. Wydawnictwo WZPiZ, Warsaw.

Górniak, L. (2015). Zarządzanie przez wartości jako metoda angażowania pracowników [Managing by values as a method of employee involvement]. Working Papers of the Cracow University of Economics, 8(944), 101-116. https://doi.org/10.15678/ZNUEK.2015.0944.0809

Grunig, J. E., \& Hunt, T. (1984). Managing public relations. Fort Worth: Harcourt Brace Jovanovich College Publishers.

Haack, P., \& Schoeneborn, D. (2015). Is decoupling becoming decoupled from institutional theory? A commentary on Wijen. Academy of Management Review, 40(2), 307-310. https://doi.org/10.5465/amr.2014.0344 
Hatch, M. J., \& Schultz, M. (2002). The dynamic of organisational identity. Human Relations, 55(8), 989-1018. https://doi.org/10.1177/0018726702055008181

Henisz, W. J., \& Zelner, B. A. (2005). Legitimacy, interest group pressures, and change in emergent institutions: the case of foreign investors and host country governments. Academy of Management Review, 30(2), 361-82. https://doi.org/10.5465/amr.2005.16387892

Hewege, C. R. (2012). A critique of the mainstream management control theory and the way forward. SAGE Open, 2(4), 1-11. https://doi.org/10.1177/2158244012470114

Hoffmann, T. (2011). Conscience and synderesis. In B. Davies \& E. Stump (Eds.), The Oxford Handbook of Aquinas. Oxford University Press.

Johnson, R. F., Stoica, R., Ailamaki A., \& Mowry, T. C. (2010). Decoupling contention management from scheduling. In ASPLOS XV Proceedings of the fifteenth edition of ASPLOS on Architectural support for programming languages and operating systems (pp. 117-128). Pittsburgh, Pennsylvania. https://doi.org/10.1145/1736020.1736035

Jonas, H. (1985). The imperative of responsibility: In search of an ethics for the technological age. University of Chicago Press.

Kahneman, D., \& Tversky, A. (1971). Belief in the law of small numbers. Psychological Bulletin, 76, 105110. https://doi.org/10.1037/h0031322

Kahneman, D., \& Tversky, A. (1973). On the psychology of prediction. Psychological Review, 80(4), 237-251. https://doi.org/10.1037/h0034747

Kahneman, D., \& Tversky, A. (1974). Judgment under uncertainty: Heuristics and biases. Science, New Series, 185(4157), 1124-1131. https://doi.org/10.1126/science.185.4157.1124

Kosewski, M. (2008). Wartości, godność i władza [Values, dignity and power]. Wydawnictwo Vizja Press \& IT, Warsaw.

Lindkvist, L., \& Llewellyn, S. (2003). Accountability, responsibility and organisation. Scandinavian Journal of Management, 19(2), 251-273. https://doi.org/10.1016/S0956-5221(02)00027-1

MacLean, T. L., \& Behnam, M. (2017). The dangers of decoupling: The relationship between compliance programs, legitimacy perception, and institutional- ized misconduct. Academy of Management Journal, 53(6).

https://doi.org/10.5465/amj.2010.57319198

Meyer, J. W., \& Rowan, B. (1977). Institutional organizations: Structure as myth and ceremony. American Journal of Sociology, 83(2), 340-363. https://doi.org/10.1086/226550

Rojek-Nowosielska, M., \& Szczepaniak, J. (2003). Odpowiedzialność Społeczna przedsiębiorstwa a teoria agencji i interesariuszy [Corporate social responsibility and agency and stakeholder theory]. Working Papers of Wrockaw University of Economics „,Nauki Humanistyczne”, 2(1008), 322-326.

Schein, E. H. (2004). Organizational culture and leadership. Jossey-Bass A Wiley Imprint, San Francisco.

Scott, R. W. (1987). Organizations: Rational, natural and open systems. Englewood Cliffs, Prentice-Hall.

Scott, R.W. (2008). Institutions and organizations (Third ed.). Sage Publications, Inc, Thousands Oaks, CA.

Ślipko, T. (1974). Zarys etyki ogólnej [Outline of general ethics]. WAM, Kraków.

Ślipko, T. (2010). Spacerem po etyce [A walk with ethics]. Kraków: Petrus.

Styczeń, T. (1993). Wprowadzenie do etyki [Introduction to ethics]. TN KUL, Lublin.

Tolbert, P. S., \& Zucker, L. G. (1983). Institutional sources of change in the formal structure of organizations: the diffusion of civil service reform. $A d$ ministrative Science Quarterly, 28(1), 22-39. https://doi.org/10.2307/2392383

Van Maanen, J., \& Schein, E. H. (1979). Toward a theory of organizational socialization. In B. M. Staw (Ed.), Research in organizational behavior (Vol. 1, pp. 209-64). JAI Press, Greenwich, CT.

Wallace, R. J. (1998). Responsibility and the moral sentiments. Harvard University Press.

Westphal, J. D., \& Zajac, E. J. (2001). Decoupling policy from practice: The case of stock repurchase progrcmis. Administrative Science Quarterly, 46(2), 202-228. https://doi.org/10.2307/2667086

Westphal, J. D., Gulati, R., \& Shortell, S. M. (1997). Customization or conformity? An institutional and network perspective on the content and consequences of TQM adoption. Administrative Science Quarterly, 42(2), 366-394. https://doi.org/10.2307/2393924 